\title{
Analysis of particle size and fractal dimensions of suspensions contained in raw sewage, treated sewage and activated sludge
}

\author{
Magdalena Kuśnierz*, Paweł Wiercik \\ Wroclaw University of Environmental and Life Science, Poland \\ Institute of Environmental Engineering \\ *Corresponding author's e-mail: magdalena.kusnierz@up.wroc.pl
}

Keywords: suspension, fractal dimension, laser granulometer, activated sludge, sewage, particle size distribution.

\begin{abstract}
The analysis of particle size in suspensions carried out with use of the laser diffraction method enables us to obtain not only information about the size of particles, but also about their properties, shape and spatial structure, determined basing on fractal dimension. The fractal dimension permits the evaluation of the interior of aggregates, at the same time showing the degree of complexity of the matter. In literature, much attention is paid to the evaluation of the fractal dimension of flocs in activated sludge, in the aspect of control of single processes, i.e. sedimentation, dehydration, coagulation or flocculation. However, results of research concerning the size of particles and the structure of suspensions existing in raw and treated sewage are still lacking.

The study presents optical fractal dimensions $D_{3}$ and particle size distributions measured with use of laser granulometer in raw and treated sewage and activated sludge collected from six mechanical-biological wastewater treatment plants located in the Lower Silesian region.

The obtained test results demonstrate that wastewater treatment plants that use both sequencing batch reactors and continuous flow reactors are more efficient at capturing suspension particles of a size up to $30 \mu \mathrm{m}$ and are characterized by an increased removal of particles of a size ranging from $30 \mu \mathrm{m}$ to $550 \mu \mathrm{m}$ to the outflow. Additionally, in the case of samples of treated sewage and activated sludge collected at the same location, at short intervals, similar particle distributions were observed. As far as the analysis of fractal dimensions is concerned, particles contained in the raw sewage suspension were characterized by the lowest values of the fractal dimension (median equals 1.89), while the highest values occurred in particles of activated sludge (median equals 2.18). This proves that the spatial structure of suspension particles contained in raw sewage was similar to a linear structure, with a large amount of open spaces, while the structure of particles contained in the activated sludge suspension was significantly more complex in the spatial aspect.
\end{abstract}

\section{Introduction}

The sensitivity and measurement accuracy of optical instruments may differ, which influences the particle size range that may be measured with use of such tools. The SAXS (small-angle X-ray scattering) and SANS (small-angle neutron scattering) techniques are successfully used for the analysis of the properties of small particles, of a size lower than one micrometre (Bizi and Baudet 2006, Patra et al. 2006, Rice et al. 1999, Weth et al. 2001). The identification of particles of a size up to several micrometres is possible if the light diffraction and light scattering methods, SLS (static light scattering) and DLS (dynamic light scattering), are used. In the $D L S$ method the fluctuation of scattered light is measured (Łomotowski et al. 2008, Martínez-Pedrero et al. 2005). The wavelength of the light source in the $S L S$ method is significantly longer than in the case of $S A X S$ or $S A N S$. The dimensioning of particles in static light source systems is based on LALLS (low angle laser light scattering) or SALLS (small angle laser light scattering).

The following terms are commonly used to describe measurement tools that measure the size of particles basing on the diffraction phenomenon and low angle light scattering technique: laser granulometer, laser diffractometer and laser diffraction spectrophotometer (Pye and Blott 2004). The low-angle light scattering technique used in modern laser granulometers allows for the measurement of scattered light intensity $I$ as a function of the wave vector $q$. The value of the wave vector $q$ is defined as the difference between the falling ray and the scattered ray in the measurement cell and it is determined by the proportion (1):

$$
q=(4 \pi m \sin (\theta / 2)) / \lambda
$$

where $m$ is the refractive index of the medium, $\theta$ is the angle of laser light scattering, and $\lambda$ is the wavelength of laser light. 
Laser granulometers allow to measure the degree of dispersion and to characterize the particles that are present in a given material in the aspect of their shape and size (Bushell 2005). These devices are also commonly used for the identification of the spatial structure of particles based on their fractal dimensions (Burszta-Adamiak et al. 2009, Chu et al. 2004, Glover et al. 2000, Thill et al. 2000, Zheng et al. 2011). Suspensions, due to their highly irregular and disordered nature, may be described in one-, two- and three-dimensional area using the three fractal dimensions $D_{f}$, where $f$ has the values of 1,2 and 3 (Gutkowska and Jodłowski 2014). Fractal dimension may be determined from a geometric power relationship between each dimensionable spatial geometry of suspension particle (i.e. periphery, area, mass or volume) and specific aggregate length scale (Lee and Kramer 2004). Fractal dimension $D_{1}$ refers to irregularity of periphery formed by the suspension particles. Two-dimension fractal dimension $D_{2}$ defines the relationship between the distance from the midpoint of the suspension-forming particle system and increase of mass within a defined area in a given distance (Chakraborti et al. 2003). Value of two-dimensional fractal dimension $D_{2}$ may be also determined with the use of relationship between the size of the analyzed suspension particle area $A$ and periphery $P$ (Lee and Kramer 2004, Rahmani et al. 2005). Fractal dimension $D_{3}$ refers to the suspension morphology and determines the density ratio of individual particles in a given volume (Rahmani et al. 2005). According to Shidaro and Zartarian (1997), three-dimensional fractal dimension $D_{3}$ illustrates the spatial distribution of particle mass. For fractal materials, mass $M$ of the suspension particles is proportional to their greatest dimension of length $l$, which increases exponentially (Jung et al. 1996, Li et al. 2006, Wu et al. 2002).

The oldest measurement technique used for assessment of fractal dimension $D_{1}, D_{2}$ and $D_{3}$ is image analysis (Bushell et al. 2002). Image is usually provided from high-quality cameras, electron, optical and confocal microscopes. The acquired binary image is analyzed with use of dedicated software enabling the assessment of aggregate morphology: length, width, periphery and projection area. Fractal dimension $D_{3}$ may be determined using information on distribution of suspended particle sizes (Lee and Kramer 2004, Logan and Klips 1995). For this purpose, the accumulated distribution analysis is used, which, as opposed to analysis of standard distributions, minimizes the risk of measurement error occurrence. Determination of dimension $D_{3}$ based on particle size distribution is feasible with use of electrical particle sensor (gauge) (Lee and Kramer 2004, Logan and Klips 1995). Application of light dispersion technique to determine the fractal dimension $D_{3}$ is however the most commonly cited in the literature.

The fractal dimension allows for the evaluation of the interior of the aggregates and their physical properties, including: porosity, density, permeability, at the same time disclosing the degree of complexity of the object ( $\mathrm{Li}$ and Logan 2001, Vainshtein et al. 2004, Zhao et al. 2013). In literature, much attention is also paid to the evaluation of the fractal dimension of flocks in activated sludge, in the aspect of control of such single processes as sedimentation, dehydration, coagulation or flocculation (Jin et al. 2003, Qi et al. 2011, Wang et al. 2014). However, there are still insufficient results of research concerning the structure of suspensions that exist in raw and treated sewage.

The proneness of organic substances in raw sewage to decomposition is determined to a large extent by the size of particles. This is why part of the organic substances and biogenic compounds of varied degree of dispersion is not removed in the course of the treatment process. This phenomenon results in an increase of pollution indicators, such as $B O D_{5}, C O D$, suspension and total phosphorus, in treated sewage. The process of removing pollutants from wastewater, taking into account the size of particles, is not well known yet. It is difficult to determine what particle sizes identified on the inflow to the wastewater treatment plant intensify the wastewater treatment process, and which particles become bound with the biomass and retained in the system. The effectiveness of wastewater treatment can be determined by the comparison of the particle size distribution $(P S D)$ before and after treatment process.

The study presents $P S D s$ and three-dimensional fractal dimensions $D_{3}$ of suspensions contained in raw sewage, treated sewage and activated sludge, determined with use of laser granulometer. The objective of this paper was to perform the analysis of PSDs for suspensions contained in raw and treated sewages and activated sludge as well as analysis of spatial structure of these suspensions with use of fractal dimensions. The authors considered whether, in the course of distribution analysis, it is possible to determine the sizes of particles, which are bound along with biomass in the sewage treatment process and whether there is an impact of structure of suspension in the sewage inflowing the sewage treatment plant on formation of activated sludge structure.

\section{Methodology of the tests}

\section{Study area and sampling points}

The tests were conducted on samples of raw sewage, treated sewage and activated sludge, collected from six mechanical-biological wastewater treatment plants located in Lower Silesia, hereinafter marked as: WWTP 1, WWTP 2, WWTP 3, $W W T P$ 4, WWTP 5 and WWTP 6. The selected wastewater treatment plants are characterised by a similar operation period, although they use different technological solutions. Wastewater treatment plants WWTP 1, WWTP 2, WWTP 3 and $W W T P 5$ operate basing on a continuous flow reactor system, while WWTP 4 and WWTP 6 use sequencing batch reactors. Specification of the individual sewage treatment plants in terms of technology is presented in Table 1.

Samples of raw sewage, treated sewage and activated sludge were collected from wastewater treatment plant based on the activated sludge process without taking into account the technological parameters of the process and the purified wastewater quality. All samples were assembled to plastic containers of a volume of $1.5 \mathrm{dm}^{3}$, in characteristic points of the treatment plant: on the inflow to the treatment plant, from activated sludge tanks and on the outflow from the plant. The material was collected each time, for all plants, between 8.00 a.m. and 12.00 p.m. Samples were stored in a refrigerator, at the temperature of $4{ }^{\circ} \mathrm{C}$, and the period between collecting samples and analysing them did not exceed 4 hours. Table 2 contains a list of conducted tests, periods during which they were carried out and the sampling points. 
Table1. Specification of the analyzed sewage treatment plants

\begin{tabular}{|c|c|c|c|}
\hline Sewage Treatment Plant & RLM & $\begin{array}{c}\text { Sewage Treatment Plant Capacity, } \\
{\left[\mathbf{m}^{3} / \mathbf{d}\right]}\end{array}$ & $\begin{array}{c}\text { Volume of treated sewage per annum } \\
\text { [thousand cubic m/year] }\end{array}$ \\
\hline WWTP 1 & 14800 & 2740 & 482,0 \\
\hline WWTP 2 & 1972 & 300 & 105,6 \\
\hline WWTP 3 & 6500 & 750 & 330,0 \\
\hline WWTP 4 & 7700 & 1800 & 376,0 \\
\hline WWTP 5 & 9829 & 1420 & 325,0 \\
\hline WWTP 6 & 2748 & 540 & 84,0 \\
\hline
\end{tabular}

Table 2. Characteristics of the number of conducted tests and the period of the experimental works

\begin{tabular}{|c|c|c|c|c|}
\hline Sample & Symbol & $\begin{array}{c}\text { Number of } \\
\text { conducted tests }\end{array}$ & $\begin{array}{c}\text { Period of the } \\
\text { experimental works }\end{array}$ & Sampling point \\
\hline Raw sewage & $R$ & 103 & $04.11 .2005-28.10 .2008$ & $\begin{array}{c}\text { Sewage treatment plant inlet } \\
\text { (after screens, before grit chamber) }\end{array}$ \\
\hline Treated sewage & $T$ & 110 & $04.11 .2005-12.11 .2012$ & $\begin{array}{c}\text { Sewage treatment plant outlet } \\
\text { (after secondary settling tank)/ SBR } \\
\text { reactor in decantation phase }\end{array}$ \\
\hline Activated sludge & AS & 109 & $02.12 .2005-12.11 .2012$ & Bioreactor \\
\hline
\end{tabular}

\section{Particle size distribution (PSD) and fractal dimension $D_{3}$}

$P S D$ was measured with use of laser granulometer Mastersizer 2000, manufactured by Malvern. In order to obtain the correct quality of the measurement data, it was necessary to prepare samples containing an appropriate concentration of suspensions. Samples of raw sewage nearly always required to be diluted with water in 1:3 proportion, even 1:6 for samples containing a high amount of suspensions. Analogically, in the case of activated sludge it was necessary to lower the concentration radically. To achieve the desired particle concentration for the analysis, $10 \mathrm{ml}$ of the activated sludge floc suspension was used. For treated sewage, the collected volume of $600 \mathrm{ml}$ was nearly always analysed without need to dilute it. Dilutions of samples were necessary for acquisition of reliable measurement results. Too high concentration of sample did not allow proper values of laser light obscuration (from 10 to $20 \%$ ) to be obtained in the measurement cell. If the particles are well dispersed we measure the scattering from each particle and avoid multiple reflection.

The fractal dimension of suspensions was determined with use of the EXCEL spreadsheet made available by the manufacturer of the laser granulometer Mastersizer 2000. Data obtained from the device, calculated in the spreadsheet, enable preparation of a diagram of the function $I(\theta)$, constituting the basis for the determination of the fractal dimension $D_{3}$. The fractal dimension was determined basing on linear regression. Linear regression estimation error was analysed by determining the confidence limits of the obtained values of straight line direction coefficients corresponding to the fractal dimensions of the analysed suspensions. The confidence limits for the straight line gradient coefficient were determined with use of t-Student distribution. This distribution was selected, as it is more suitable for small samples than the standard normal distribution. The level of probability for which the calculations were performed, was determined at the confidence level of $95 \%$. Fractal dimension estimation errors for all samples did not exceed the value of \pm 0.08 . Only the most probable values of fractal dimensions are discussed in the further sections of the study, without providing the ranges of estimation errors.

Statistical analyses based on the obtained test results were conducted with use of STATISTICA 10 PL software.

\section{Results of the tests}

\section{Distributions of the density of occurrence of suspension particles}

During several years of monitoring the test sites, differences in the composition and size of suspension particles identified in activated sludge tanks and on the inflow and outflow from the wastewater treatment plant were determined. A wide range of sizes of solid particles was defined as the percentage share of volume $v$ of particles of diameter $d_{i}$ and presented in form of the function $F(d)$.

In most cases $P S D s$ in raw sewage were multi-modal (Fig. 1). Extremely high variability of PSDs, resulted, among others, from the process of transporting sewage to the wastewater treatment plant. However, basing on the results of the conducted research, the authors were unable to draw conclusions concerning the influence of the sewage system on the distribution of suspension particles present in the raw sewage. The highest share in the suspension volume in the raw sewage had particles of a size ranging from $12 \mu \mathrm{m}$ to $168 \mu \mathrm{m}$. The size of the smallest particles identified in the raw sewage ranged from $0.24 \mu \mathrm{m}$ to $2.40 \mu \mathrm{m}$.

In the samples of treated sewage one- or bimodal distributions were identified. Contrary to samples collected at long intervals, for samples collected at the same location, at short intervals similar PSDs were observed (Fig. 2). One 
should mention that the analysis of particle size distribution was performed on the samples from the sewage treatment plant to which no chemical precipitation with metal salts was applied. Particles of sizes ranging from $26 \mu \mathrm{m}$ to $250 \mu \mathrm{m}$ were dominant in the volume of treated sewage. The lowest identified particle sizes ranged from $0.20 \mu \mathrm{m}$ to $2.90 \mu \mathrm{m}$. The range of particle sizes was similar as for the activated sludge, which is related to the phenomenon of sludge flocs outflow from the settling tank along with treated sewage. Distribution of particle sizes determined for activated sludge and treated sewage in most cases overlap in the area of sizes of activated sludge sizes, however the ranges of particle sizes have frequently different volume percentage values. In the case of several distributions generated for treated sewage presented in Figure 2, a higher percentage share in the total volume of particles for sizes above $300 \mu \mathrm{m}$ and below $10 \mu \mathrm{m}$ is identified comparing to activated sludge. Higher percentage values for the particles above $300 \mu \mathrm{m}$ may demonstrate improper outflow of larger suspension agglomerates from the settling tanks.
In activated sludge samples uni-modal $P S D s$ were prevalent (Fig. 3). Activated sludge demonstrated relatively constant granulometric composition and this composition depended on time and place of sampling for analytical purposes. Within the same sewage treatment plant, changes of particle sizes distributions were minor. The highest share of particle size in the suspension volume was $35 \mu \mathrm{m}$ to $337 \mu \mathrm{m}$, and the lowest identified particle sizes ranged from $0.40 \mu \mathrm{m}$ to $2.59 \mu \mathrm{m}$. In activated sludge, the presence of colloidal and supracolloidal $(<1 \mu \mathrm{m})$ range particles can result in the deterioration of settling processes and dewatering conditions.

The limits of ranges of the size of particles identified in the suspension present in selected samples of raw sewage, treated sewage and activated sludge presents Table 3.

When comparing PSDs and the ranges of occurrence of specific particle sizes in raw and treated sewage it is difficult to estimate which particle sizes are captured in the wastewater treatment plant system and which ones are removed with the outflow from secondary sedimentation tanks. Similar particle size ranges occur both on the inflow and on the outflow from

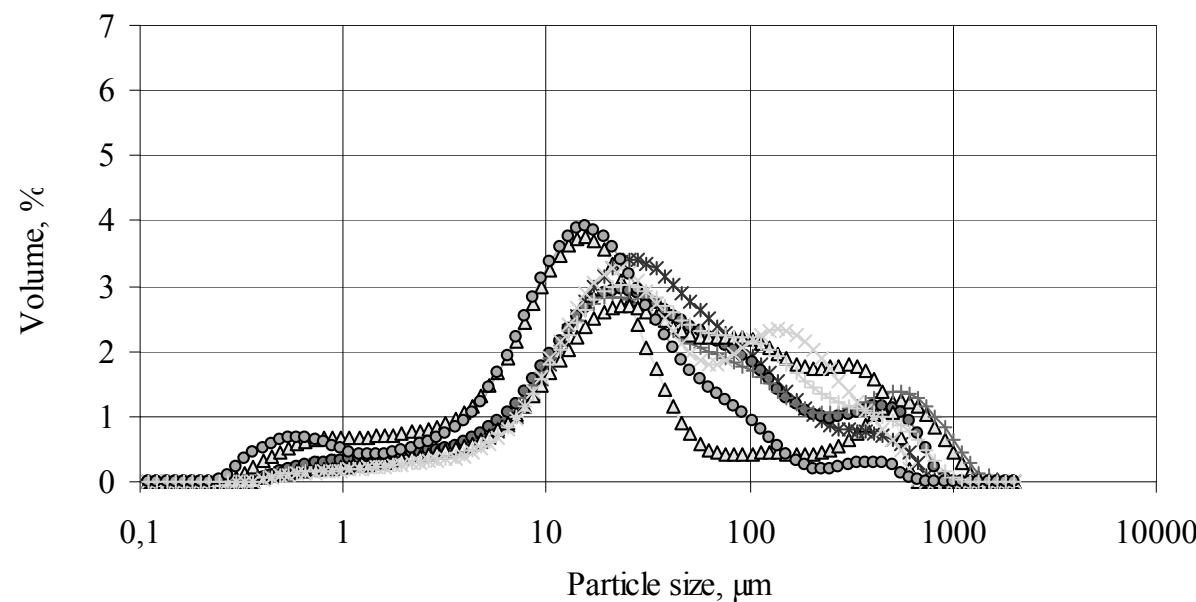

$\Delta$ sVII06 $\rightarrow$ sX06 - sXI06 -

Fig. 1. Percentage share of particles of diameter $d_{i}$ in the total volume of raw sewage samples collected from the WWTP 1 plant

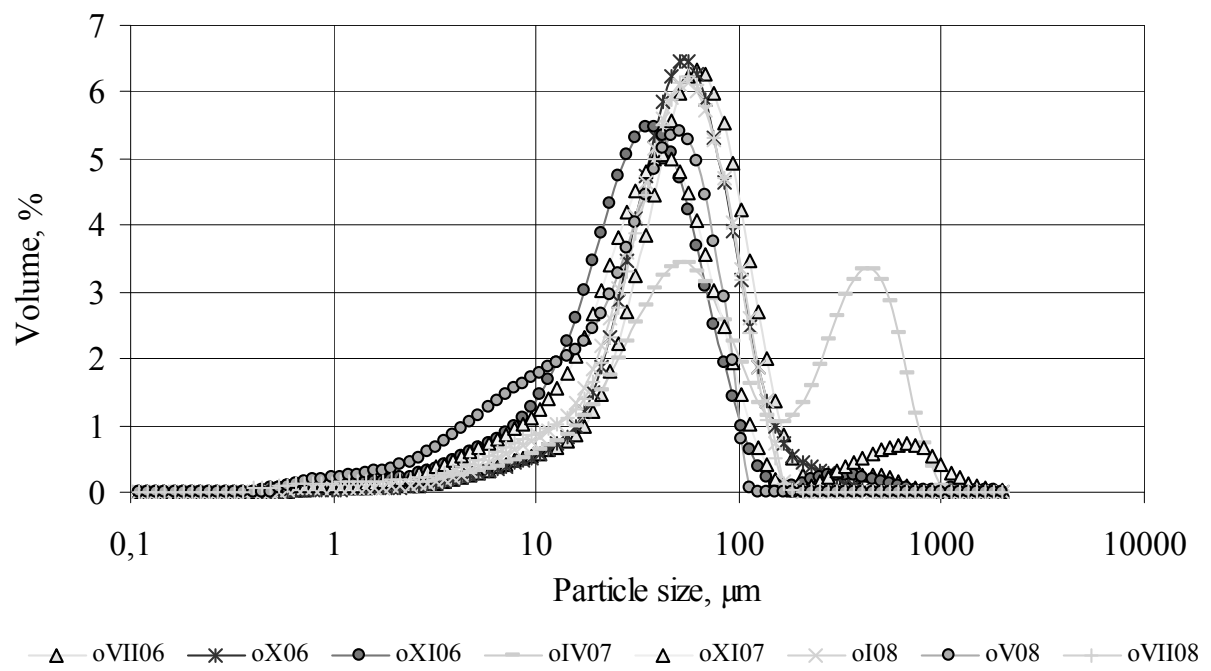

Fig. 2. Percentage share of particles of diameter $d_{i}$ in the total volume of treated sewage samples collected from the WWTP 1 plant 


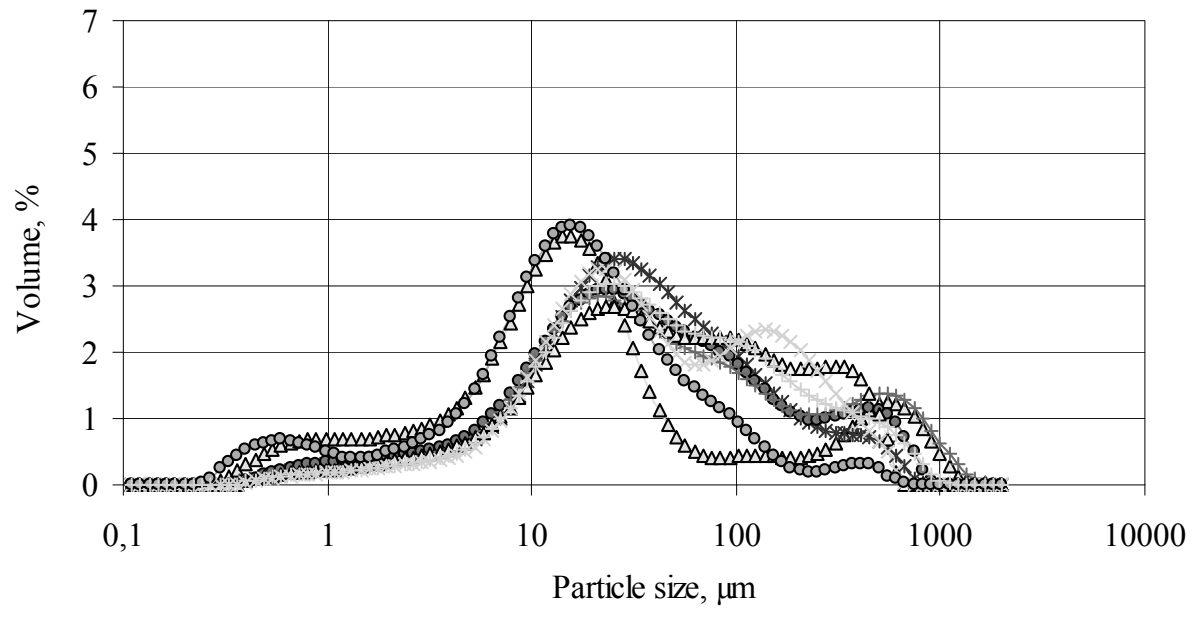

$\Delta$ sVII06 $\rightarrow$ sX06 - sXI06 — sXII06 $\Delta$ sXI07 - sI08

Fig. 3. Percentage share of particles of diameter $d_{i}$ in the total volume of activated sludge samples collected from the WWTP 1 plant

Table 3. Borderline particle sizes identified in selected samples of raw sewage, treated sewage and activated sludge collected from individual wastewater treatment plants

\begin{tabular}{|c|c|c|c|c|c|c|c|c|c|c|c|c|}
\hline \multirow{2}{*}{ Date } & \multicolumn{2}{|c|}{ WWTP 1} & \multicolumn{2}{|c|}{ WWTP 2} & \multicolumn{2}{|c|}{ WWTP 3} & \multicolumn{2}{|c|}{ WWTP 4} & \multicolumn{2}{|c|}{ WWTP 5} & \multicolumn{2}{|c|}{ WWTP 6} \\
\hline & $\min$ & $\max$ & $\min$ & $\max$ & $\min$ & $\max$ & $\min$ & $\max$ & $\min$ & $\max$ & $\min$ & $\max$ \\
\hline \multicolumn{13}{|c|}{ Borderline particle sizes identified in raw sewage, $\mu \mathrm{m}$} \\
\hline 04.11 .2005 & 0.442 & 000.000 & 1.951 & 1218.929 & 0.400 & 336.391 & 0.362 & 1218.929 & 0.442 & 2000.000 & 0.362 & 1345.826 \\
\hline 02.12 .2005 & 0.269 & & 1.951 & & 0.244 & & 362 & & 0.442 & & .400 & \\
\hline 09.05 .2006 & 0.244 & & 0.400 & 2000.000 & n.d. & n.d. & .400 & & 0.538 & & .400 & 00.000 \\
\hline 06.10 .2006 & 0.362 & 820.233 & 0.442 & & 0.362 & 1218.929 & 0.362 & & 0.538 & 2000.000 & 0.400 & \\
\hline 04.04 .2 & 0.442 & 625 & 0.442 & & 0.362 & & .400 & & 0.538 & 826 & 0.362 & \\
\hline & 362 & & 0.442 & & 0.328 & & & & 0.442 & & 0.400 & \\
\hline 08.07 .2008 & 0.400 & & 0.328 & & & & & & 0.442 & & .400 & \\
\hline & 0.362 & & 0.442 & & 0.3 & & & & 0.442 & & 0.362 & \\
\hline \multicolumn{13}{|c|}{ Borderline particle sizes identified in activated sludge, $\mu \mathrm{m}$} \\
\hline & 0.442 & & 1.951 & & 0.488 & & 3.202 & & 1.077 & & 2.379 & \\
\hline & 0.595 & & & & n.d. & & & & & & 0.400 & \\
\hline & & & & & & & & & & & & \\
\hline 04.0 & 0.538 & 23 & 1.767 & & 0.488 & 00 & 2.379 & & 1.450 & 826 & 2.379 & \\
\hline 29.11 & 0.400 & & 51 & & 0.269 & & 379 & & 1.313 & & n.d. & \\
\hline 08.07 & 0.442 & & 79 & & 0.362 & & 79 & & 50 & 33 & 2.626 & 826 \\
\hline & & & & & & & & & & & 351 & \\
\hline & & & & & & & & & & & 1.78 & \\
\hline 21. & 2.240 & & 2.24 & & n.d. & & & & 2.24 & & n.d. & \\
\hline 012 & 2.240 & & 3.17 & & n.d. & & 2.52 & & 2.24 & & n.d. & d. \\
\hline 12.11.2012 & 0.0439 & & n.d.. & & 2.825 & 2000.000 & n.d. & & 2.000 & & n.d. & \\
\hline \multicolumn{13}{|c|}{ Borderline particle sizes identified in treated sewage, $\mu \mathrm{m}$} \\
\hline 05 & 0.362 & & 0.800 & & 0.442 & 2000.000 & 2.900 & & 0.976 & & .328 & 348 \\
\hline .2005 & 0.442 & 820.233 & 1.313 & .077 & 0.362 & 1218.929 & 0.976 & 1485.933 & 0.200 & .903 & 0.400 & \\
\hline & & & & & 0.269 & & & & & & 0.400 & .406 \\
\hline 04.04 .2007 & 0.725 & & 1.951 & 2000.000 & 0.442 & 1345.826 & 1.767 & 1.422 & 0.800 & 304.673 & 0.362 & 1.422 \\
\hline 29.11 .2007 & 0.442 & & & & & & & & & 2000.000 & 0.400 & 3.998 \\
\hline 08.07 .2008 & 0.400 & 185.688 & 1.951 & 1103.998 & 0.269 & 499.903 & 0.538 & 551.945 & 0.595 & 410.077 & 0.488 & 185.688 \\
\hline & & & 1.313 & & 0.328 & & 0.725 & & 0.538 & & 0.800 & 371.411 \\
\hline 21.12.2011 & 2.000 & 2000.000 & 2.825 & 2000.000 & n.d. & n.d. & n.d. & n.d. & 2.244 & 399.053 & n.d. & n.d. \\
\hline 13.03.2012 & 2.000 & 893.3672 & 1.2619 & 316.979 & & & 1.782 & 709.626 & 2.244 & & n.d. & n.d. \\
\hline 12.11.2012 & 1.125 & 1415.892 & n.d. & n.d. & 2.000 & 2000.000 & n.d. & n.d. & 1.125 & 709.627 & n.d. & n.d. \\
\hline
\end{tabular}

n.d. - no data 
the wastewater treatment plant. Figure 4 presents the calculated values of differences between particle volume recorded on the inflow and on the outflow from the plant, in form of bar diagrams. Due to the large amount of data Figure 4 shows the mean values calculated with respect to all PSDs. The analysis of the obtained suspension PSDs for specific wastewater treatment plants enables us to notice that throughout the measurement range from $0.20 \mu \mathrm{m}$ to $2000 \mu \mathrm{m}$ part of the suspension particles volume was retained in the treatment plant system. A decrease in volume in the given particle size group, based on the comparison between inflow and outflow, means that such particles are bound with the biomass and retained in the system. On the outflow from the wastewater treatment plant, as compared with the inflow, the volume of particles up to $30 \mu \mathrm{m}$ decreased, and the volume of particles ranging from $30 \mu \mathrm{m}$ to $550 \mu \mathrm{m}$ increased. Most of the particles of a size exceeding $550 \mu \mathrm{m}$ were retained in secondary tanks. Exceptions are wastewater treatment plants $W W T P 6$ and $W W T P 3$, where it was demonstrated that particles of sizes ranging from $1 \mu \mathrm{m}$ to $30 \mu \mathrm{m}$ were removed to the outflow, although it is worth noting that a deterioration of the outflow from these plants was often noted during the period of the experiment.

PSDs were also compared in the aspect of mean diameter values for sets of particles. Average particle set diameters may be determined directly basing on granulometric composition or indirectly, basing on the parameters of lognormal distribution described by equation (2).

$$
d n\left(d_{i}\right)=100 \% \cdot \frac{1}{\sqrt{2 \pi} \ln \sigma} \exp \left[-\frac{\left(\ln d_{i}-\ln X\right)^{2}}{2 \ln \sigma^{2}}\right] d\left(\ln d_{i}\right)
$$

where $X$ is the geometric mean of a set of particles, and $\sigma$ is the geometric standard deviation.

Basing on PSDs the values of mean diameters $D(3.2)$ and $D(4.3)$ were determined. The diameter $D(3.2)$ is a measure of the active surface of particles creating the suspension, while $D(4.3)$ is a measure of the mass of particles in the suspension. The active surface of particles increases along with the decrease in the $D(3.2)$ diameter, enhancing their efficiency in catalysing chemical processes.

The lowest values of $D(3.2)$ diameters were noted for suspensions contained in raw sewage. For the analysed raw sewage samples, with one exception of the WWTP 2 treatment plant, the $D(3.2)$ diameter was characterized by sizes ranging from $3.6 \mu \mathrm{m}$ to $35.4 \mu \mathrm{m}$. The $D(4.3)$ diameter was characterized by sizes ranging from $21.9 \mu \mathrm{m}$ to $254.3 \mu \mathrm{m}$.

In the case of treated sewage and activated sludge, the $D$ (3.2) diameter was in range from $1.9 \mu \mathrm{m}$ to $123.0 \mu \mathrm{m}$. The highest differentiation in the value of $D(3.2)$ diameters was noted for suspensions in treated sewage, however, the highest values of $D(3.2)$ were nodded for activated sludge. The $D(4.3)$ diameter was characterized by sizes ranging from $14.6 \mu \mathrm{m}$ to $596.2 \mu \mathrm{m}$, with a dominance of smaller sizes, which proves that a suspension composed of such particles may be classified as hardly sedimenting.

The analysis of the median values of the obtained result sets demonstrated that the mass of suspension particles in raw sewage is concentrated within the range of diameters higher than diameter values identified in wastewater from the treatment plant (Table 4). Additionally, the values of the mean diameter $D(3.2)$ in raw sewage were lower than those of suspensions present in the activated sludge, which means that the active surface of particles present in raw sewage suspension is much larger, and thus these particles are characterised by better sorption and catalytic properties than particles found in activated sludge suspension.

\section{Characteristics of the obtained results of fractal dimensions of suspensions}

Fractal dimensions of suspensions were determined basing on PSDs based on volume. This kind of distributions was

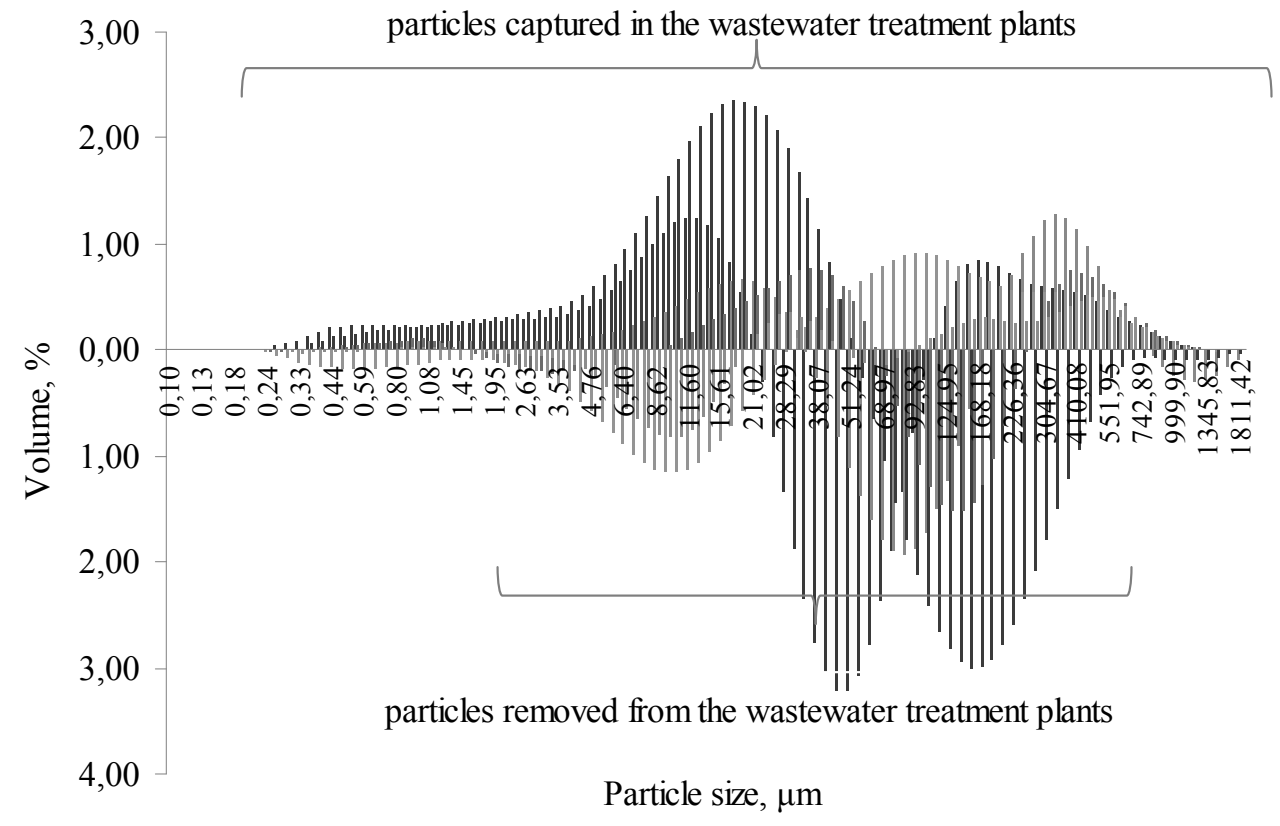

Fig. 4. The calculated values of differences between particle volume recorded on the inflow and on the outflow from all wastewater treatment plants 
also used in research presented in works by Logan and Klips (1995). Fractal dimensions determined in such way may take values from 1 to a maximum of 3 . Suspensions present in the activated sludge were characterised by a more cohesive structure $\left(D_{3}=1.99-2.32\right)$ than suspensions in raw and treated sewage, where the fractal dimension of suspension ranged, respectively, from 1.47-2.24 for raw sewage and 1.37-2.21 for treated sewage. Figure 5 presents a comparison of fractal dimensions of suspensions in a set of block diagrams, showing the determined values of medians, quartiles $25 \%$ and $75 \%$ and minimum and maximum values for $D_{3}$ dimensions. The median of the set of fractal dimension values $D_{3}$ for raw sewage was 1.89 , for treated sewage 1.94 and for activated sludge -2.18 . Lower values of the fractal dimension of suspensions present in raw sewage demonstrate that their spatial structure resembled straight structures, with a large amount of open spaces, while the activated sludge suspension is characterised by a much higher degree of matter concentration. Flocculated structure is an expanded feathery structure, which explains the higher values of fractal dimensions for this group of suspensions.

The fractal dimension values were also subject to concentration analysis carried out with use of the Ward method, with aim to determine statistically significant similarities among the obtained test results. Figure 6 shows a concentration tree diagram obtained for all test results of fractal dimensions of suspensions contained in raw sewage, treated sewage and activated sludge. Vectors describing the fractal dimensions of suspensions contained in raw sewage created a clear separate cluster compared to the vectors of fractal dimensions of suspensions in activated sludge. The results of cluster analysis extracted essentially two different types of spatial structures of suspensions, with a large amount of open spaces and expanded feathery structure. The fractal dimension values of suspensions contained in raw sewage originating from various sewage systems showed similarities only to others within their group and partly between others within their group and treated sewage for WWTP 3, WWTP 4, WWTP 5. In the case of treated sewage fractal dimension values showed the similarity between the values obtained for the activated sludge. As far as treated sewage and activated sludge are concerned, the results of cluster analysis confirmed the commonly known thesis that often the composition and nature of suspensions that are present in treated sewage are influenced by the composition and nature of suspensions present in activated sludge, as suspensions composed of particles removed with the outflow from activated sludge tanks are often identified in treated sewage.

Table 4. Medians of the set of diameters $D(4.3)$ and $D(3.2)$ in samples of raw sewage, treated sewage and activated sludge collected from individual wastewater treatment plants

\begin{tabular}{|c|c|c|c|c|c|c|c|}
\hline Sample & $\begin{array}{c}\text { Mean } \\
\text { diameter }\end{array}$ & WWTP 1 & WWTP 2 & WWTP 3 & WWTP 4 & WWTP 5 & WWTP 6 \\
\hline \multirow{2}{*}{ Raw sewage } & $\mathrm{D}(4.3)$ & 89.202 & 139.030 & 85.231 & 91.424 & 121.618 & 90.624 \\
\cline { 2 - 8 } & $\mathrm{D}(3.2)$ & 10.896 & 29.022 & 9.951 & 10.232 & 18.135 & 11.051 \\
\hline \multirow{2}{*}{ Activated sludge } & $\mathrm{D}(4.3)$ & 56.960 & 113.027 & 58.499 & 191.684 & 118.131 & 154.662 \\
\cline { 2 - 9 } & $\mathrm{D}(3.2)$ & 21.584 & 48.593 & 12.327 & 79.255 & 42.410 & 61.633 \\
\hline \multirow{2}{*}{ Treated sewage } & $\mathrm{D}(4.3)$ & 50.624 & 126.596 & 43.058 & 162.811 & 100.167 & 53.805 \\
\cline { 2 - 8 } & $\mathrm{D}(3.2)$ & 20.972 & 41.763 & 8.052 & 52.585 & 27.638 & 11.460 \\
\hline
\end{tabular}

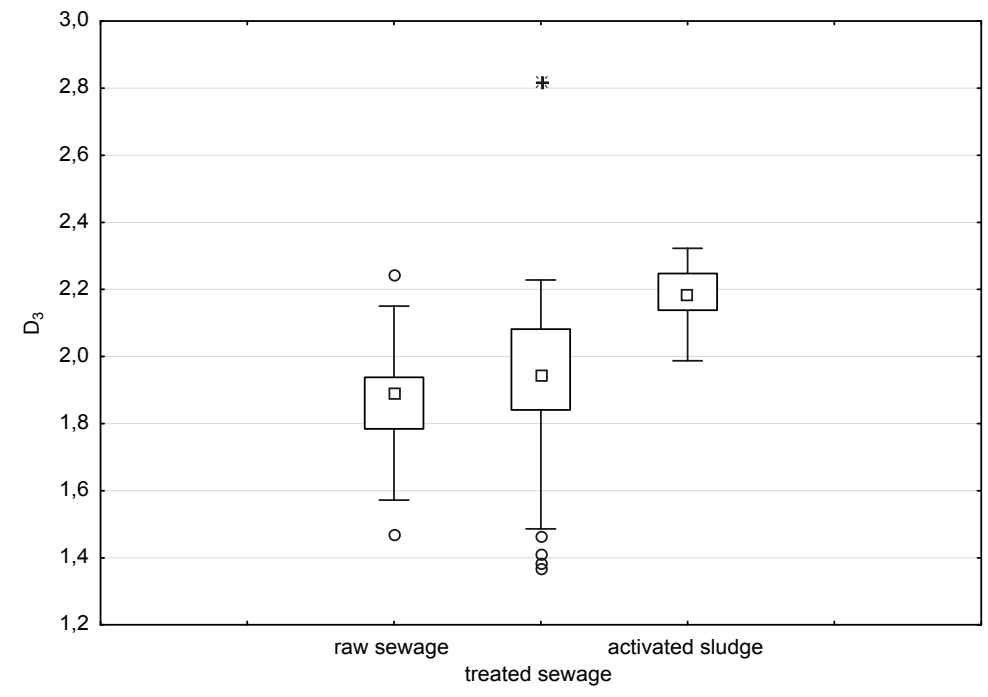

$\square$ Median $\square 25 \%-75 \%$ I Non-Outlier Range o Outliers + Extreme

Fig. 5. Comparison of fractal dimension values for suspensions in raw sewage, activated sludge and treated sewage 


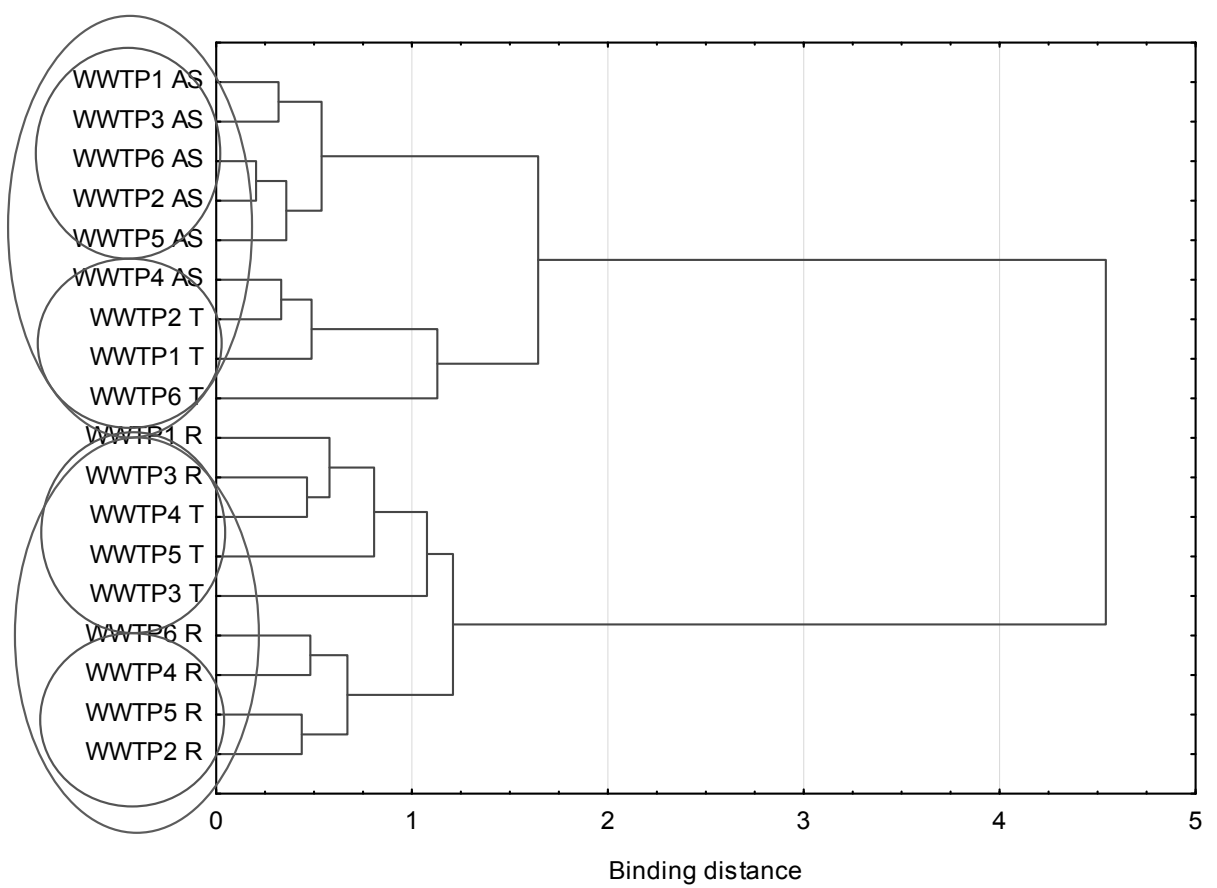

Fig. 6. Dendrograms of bonds for all obtained vectors of fractal dimensions of suspensions contained in raw sewage (R), treated sewage $(T)$ and activated sludge (AS)

\section{Discussion}

The measurements recorded with use of laser granulometer show a high variability of the PSDs in suspensions present in raw sewage and a lower variability in treated sewage on the outflow from the sedimentation tank. The variability was the lowest in samples of activated sludge. As far as the samples of treated sewage and activated sludge collected at the same location at short intervals, are concerned, similar distributions of particle occurrence in the suspension were observed. This proves the existence of seasonal changes in the distribution of particle sizes in activated sludge and in the suspension removed from the treatment plant with treated sewage. The dominant PSDs obtained in activated sludge samples were onemodal. Onemodal systems in PSDs for activated sludge were also observed by Gonze et al. (2003) and Chaignon et al. (2002), while the existence of bimodal systems was proven, among others, in studies conducted by Lower (quot. Houghton et al. 2002). Particle sizes present in raw and treated sewage and activated sludge covered practically the whole measurement range from $0.20 \mu \mathrm{m}$ to $2000 \mu \mathrm{m}$. The smallest particles were identified in raw sewage. The obtained test results demonstrate that wastewater treatment plants that use both sequencing batch reactors and continuous flow reactors cause the capturing of suspension particles. The occurrence of smaller particle size volumes (for particles up to $30 \mu \mathrm{m}$ ) in treated sewage in comparison to raw sewage lowers the amount of pollutants observed in the outflow, absorbed on the smallest suspension fractions. Pollutants are adsorbed on particles of various sizes, although Sansalone and Tribouillard (1999) determined that, for example, heavy metals are adsorbed more quickly on the smallest particles. The particle removal efficiency of the treatments has also been found by Garcia-Mesaet et al. 2012. The higher reduction of particle removal was achieved by the membrane bioreactor and the medium-load activated sludge systems.
Particles of the diameter up to $250 \mu \mathrm{m}$ accounted for the highest percentage shares in particle volume for treated sewage, while in the case of raw sewage this applies to particles of a diameter up to $160 \mu \mathrm{m}$ and particles up to $330 \mu \mathrm{m}$ for activated sludge samples. Similar results concerning the identified particle sizes in activated sludge, of approx. $300 \mu \mathrm{m}$, were obtained by Defrance et al. (2000). On the other hand, Wiśniewski and Grasmick (1998) obtained a mean particle size exceeding $500 \mu \mathrm{m}$ for sludge collected from the activated sludge chamber and the determined size of recirculated sludge flocs ranged from $20 \mu \mathrm{m}$ to $500 \mu \mathrm{m}$. In studies conducted by Jordan et al. (1995) approx. $44 \%$ of the population was characterised by particle sizes ranging from $68.3 \mu \mathrm{m}$ to $183 \mu \mathrm{m}$.

The differentiation of the obtained fractal dimension values suggests that the spatial structure of suspensions contained in activated sludge, raw and treated sewage, is different for each of the analysed treatment plants. The highest values of $D_{3}$ dimensions were noted for activated sludge, and the lowest for suspensions contained in raw sewage. At low $D_{3}$ values, the shape of suspension particles resembles elongate segments. As the value increases, suspension surfaces expand, creating spatial structures. The fractal dimension values obtained for raw and treated sewage are difficult to compare due to a low number of conducted studies in this area. The fractal dimension values obtained for activated sludge during the test period were often higher than 2. Such fractal dimension leads to the expansion of suspension surfaces, creating spatial structures, which might seem to increase the content of water in the sludge, and, as a result, lead to deterioration in sludge sedimentation. However, Turchiuli and Fargues (quot. Zaho et al. 2013) stated that the sludge bound-water content is decreased with the floc fractal dimension: less compact flocs contained more water but less bound water. This aspect requires further analysis.

The obtained fractal dimension values for activated sludge were similar to those obtained in the studies by $\mathrm{Wu}$ et al. 
(2002), Li and Yuan (2002), Waite (1999). However, many authors have reported that the average fractal dimension of the flocs depended on the coagulation conditions (Zaho et al. 2013, Zheng et al. 2011). What is more, two flocs of the same size can have different fractal dimensions, although large flocs are expected to exhibit a wider range of fractal dimensions than the small flocs (Vahedi and Gorczyca, 2012). The obtained results for activated sludge demonstrate that activated sludge flocs have different abilities to adsorb pollutants. Flocs characterized by a more compact structure (high value of fractal dimension but smaller specific surface area) have a worse ability to adsorb pollutants than flocs characterized by a lower value of fractal dimension (Smoczyński et al. 2014). Additionally, Li et al. (2008) found that floc size $(D(4.3))$ and floc structure $\left(D_{3}\right)$ have also strong correlations with filament index $(F I)$. Meng et al. (2006) found that floc size increased as FI increased and FI increased as the $D_{f}$ decreased.

\section{Conclusion}

The phenomena and processes that occur with the participation of suspensions are characterised by high complexity. It is necessary to develop new research methods and measurement techniques in order to analyse them in the qualitative and quantitative aspects. Techniques based on the light scattering phenomenon occurring in equipment known as laser granulometers enable us to obtain information concerning both the properties of particles creating the suspension and their spatial structure, basing on their fractal dimensions.

The test results demonstrate that:

Wastewater treatment plants that use both sequencing batch reactors and continuous flow reactors are more efficient at capturing suspension particles of a size up to $30 \mu \mathrm{m}$ and are characterised by an increased removal of particles of a size ranging from $30 \mu \mathrm{m}$ to $550 \mu \mathrm{m}$.

Samples of treated sewage and activated sludge collected at the same location are characterized by similar particle size distribution. This resulted from the presence of particles discharged with the outflow from activated sludge tanks in treated sewage. For raw sewage, no unequivocal relationship between distributions of particle sizes acquired for the inflow activated sludge and the sizes of particles for raw sewage was demonstrated.

The highest values of $D_{3}$ fractal dimensions were noted for activated sludge, and the lowest ones for suspensions contained in raw sewage. This proves that the spatial structure of suspensions present in raw sewage resembled linear structures, with a large amount of open spaces, while the structure of particles creating the suspension in activated sludge was much more spatially developed, in form of a feathery structure.

\section{References}

Bizi, M. \& Baudet, G. (2006). Contribution of static light scattering to the textural characterization of large aggregates, Journal of Colloid and Interface Science, 300, pp. 200-209.

Burszta-Adamiak, E., Łomotowski, J. \& Kęszycka, M. (2009). Analyzing the spatial structure of suspended solids in natural water, Ochrona Środowiska, 31, 3, pp. 65-68. (in Polish)

Bushell, G. (2005). Forward light scattering to characterize structure of flocs composed of large particles, Chemical Engineering Journal, 111, pp. 145-149.
Bushell, G., Yan, Y.D., Woodfield, D., Raper, J. \& Amal, R. (2002). On techniques for the measurment of the mass fractal dimension of aggregates, Advances in Colloid and Interface Science, 95, pp. 1-50.

Chaignon, V., Lartiges, B.S., El Samrani, A. \& Mustin, C. (2002). Evolution of size distribution and transfer of mineral particles between flocs in activated sludges: an insight into floc exchange dynamics, Water Research, 36, pp. 676-684.

Chakraborti, R.K., Gardner, K.H., Atkinson, J.F. \& Van Benschoten, J.E. (2003). Changes in fractal dimension during aggregation, Water Research, 37, pp. 873-883.

Chu, C.P. \& Lee, D.J. (2004). Multiscale structures of biological focs, Chemical Engineering Science, 59, pp. 1875-1883.

Defrance, L., Jaffrin, M.Y., Gupta, B., Paullier, P. \& Geaugey, V. (2000). Contribution of various constituents of activated sludge to membrane bioreactor fouling, Bioresource Technology, 73, 2, pp. 105-112.

Garcia-Mesa, J.J., Delgado-Ramos, F., Muñio, M.M., Hontoria, E. \& Poyatos, J.M. (2012). Comparison of activated sludge technologies by particle size analysis, Water Air and Soil Pollution, 223, pp. 4319-4331.

Glover, S.M., Yan, Y., Jameson, G.J. \& Biggs, S. (2000). Bridging flocculation studied by light scattering and settling, Chemical Engineering Journal, 80, pp. 3-12.

Gonze, E., Pillot, S., Valette, E., Gonthier,Y. \& Bernis, A. (2003). Ultrasonic treatment of an aerobic activated sludge in a batch reactor, Chemical Engineering and Processing, 42, pp. 965-975.

Gutkowska, E. \& Jodłowski, A. (2014). Fractal and morphological analysis of algae cells agglomerates, Interdyscyplinarne zagadnienia w inżynierii i ochronie środowiska, Wrocław 2014. (in Polish)

Houghton, J.I., Burgess, J.E. \& Stephenson, T. (2002). Off-line particle size analysis of digested sludge, Water Research, 36, pp. 4643-4647.

Jin, B., Wilén, B. \& Lant, P. (2003). A comprehensive insight into floc characteristics and their impact on compressibility and settleability of activated sludge, Chemical Engineering Journal, 95, pp. 221-234.

Jordan, F., Zartarian, F., Thomas, F., Block, J.C., Bottero, J.Y., Villemin, G., Urbain, V. \& Manem, J. (1995). Chemical and structural (2D) linkage between bacteria within activated sludge flocs, Water Research, 29, pp. 1639-1647.

Jung, S.J., Amal, R. \& Raper, J.A. (1996). Monitoring effects of shearing on floc structure using small-angle light scattering, Powder Technology, 88, pp. 51-54.

Lee, C. \& Kramer, T.A. (2004). Prediction of three-dimensional fractal dimensions using the two-dimensional properties of fractal aggregates, Advances in Colloid and Interface Science, 112, pp. 49-57.

Li, J., Li, Y., Ohandja, D.G., Yang, F., Wong, F.S. \& Chua, H.C. (2008). Impact of filamentous bacteria on properties of activated sludge and membrane-fouling rate in a submerged MBR, Separation and Purification Technology, 59, 3, pp. 238-243.

Li, T., Zhu, Z., Wang, D., Yao, C. \& Tang, H. (2006). Characterization of floc size, strength and structure under various coagulation mechanisms, Powder Technology, 168, pp. 104-110.

Li, X.Y. \& Logan, B.E. (2001). Permeability of fractal aggregates, Water Research, 35, 14, pp. 3373-3380.

Li, X. \& Yuan, Y. (2002). Settling velocities and permeabilities of microbial aggregates, Water Research, 36, pp. 3110-3120.

Logan, B.E. \& Kilps, J.R. (1995). Fractal dimensions of aggregates formed in different fluid mechanical environments, Water Research, 29, pp. 443-453.

Łomotowski, J., Burszta-Adamiak, E., Kęszycka, M. \& Jary, Z. (2008). Metody i techniki optyczne w badaniach zawiesin. Wydawnictwo PAN, Instytut Badań Systemowych, Warszawa 2008. 
Martínez-Pedrero, F., Tirado-Miranda, M., Schmitt, A. \& Callejas-Fernández, J. (2005). Aggregation of magnetic polystyrene particles: A light scattering study, Colloids and Surfaces A: Physicochemical Engineering Aspects, 270-271, pp. 317-322.

Meng, F., Zhang, H., Yang, F., Li, Y., Xiao, J. \& Zhang, X. (2006). Effect of filamentous bacteria on membrane fouling in submerged membrane bioreactor, Journal of Membrane Science, 272, pp. $161-168$.

Patra, A.K., Nair, S., Tyagi, A.K., Sen, D., Mazumder, S. \& Ramanathan, S. (2006). Small-angle neutron scattering investigations on fractal aggregation and sintering behavior of La1-xCaxCrO3 synthesized by a combustion process, Materials Science and Engineering, 127, pp. 180-185.

Pye, K. \& Blott, S.J. (2004). Particle size analysis of sediments, soils and related particulate materials for forensic purposes using laser granulometry, Forensic Science International, 144, pp. 19-27.

Qi, Y., Thapa, K.B. \& Hoadley, A.F.A. (2011). Application of filtration aids for improving sludge dewatering properties - A review, Chemical Engineering Journal, 171, pp. 373-384.

Rahmani, N.H.G., Dabros, T. \& Masliyah, J.H. (2005). Fractal structure of asphaltene aggregates, Journal of Colloid and Interface Science, 285, pp. 599-608.

Rice, J.A., Tombácz, E. \& Malekani, K. (1999). Applications of light and X-ray scattering to characterize the fractal properties of soil organic matter, Geodermia, 88, pp. 251-264.

Sansalone, J.J. \& Tribouillard, T. (1999). Variation in characteristics of abraded roadway particles as a function of particle size - Implications for water quality and drainage, Journal of Transportation Research Record, 1690, pp. 153-163.

Shidaro, D. \& Zartarian, F. (1997). Characterization of activated sludge flocs structure, Water Science Technology, 36, pp. 313-320.

Smoczyński, L., Ratnaweera, H., Kosobucka, M. \& Smoczyński, M. (2014). Image analysis of sludge aggregates, Separation and Purification Technology, 122, pp. 412-420.
Thill, A., Lambert, S., Moustier, S., Ginestet, P., Audic, M.J. \& Bottero, J.Y. (2000). Structural interpretations of static light scattering patterns of fractal aggregates, Journal of Colloid and Interface Science, 228, pp. 386-392.

Waite, T.D. (1999). Measurement and implications of flocs structure in water and wastewater treatment, Colloids and Surfaces A: Physicochemical and engineering aspects, 151, pp. 27-41.

Wang, L.F., Wang, L.L., Li, W.W., He, D.Q., Jiang, H., Ye, X.D., Yuan, H.P., Zhu, N.W. \& Yu, H.Q. (2014). Surfactant-mediated settleability and dewaterability of activated sludge, Chemical Engineering Science, 116, pp. 228-234.

Weth, M., Mathias, J., Emmerling, A., Kuhn, J. \& Fricke, J. (2001). The structure of carbon blacks measured with (Ultra)-Small Angle X-Ray Scattering, Journal of Porous Materials, 8, pp. 319-325.

Wisniewski, C. \& Grasmick, A. (1998). Floc size distribution in a membrane bioreactor and consequences for membrane fouling, Colloids and Surfaces, 138, pp. 403-411.

Wu, R.M., Lee, D.J., Waite, T.D. \& Guan, J. (2002). Multilevel structure of sludge flocs, Journal of Colloid and Interface Science, 252, pp. 383-392.

Vainshtein, P., Shapiro, M. \& Gutfinger, C. (2004). Mobility of permeable aggregates: effects of shape and porosity, Aerosol Science, 35, pp. 383-404.

Vahedi, A. \& Gorczyca, B. (2012). Predicting the settling velocity of flocs formed in water treatment using multiple fractal dimensions, Water Research, 46, 13, pp. 4188-4194.

Zheng, H., Zhu, G., Jiang, S., Tshukudu, T., Xiang, X., Zhang, P. \& He, Q. (2011). Investigations of coagulation - flocculation process by performance optimization, model prediction and fractal structure of flocs, Desalination, 269, pp. 148-156.

Zhao, P., Ge, S., Chen, Z. \& Li, X. (2013). Study on pore characteristics of flocs and sludge dewaterability based on fractal methods (pore characteristics of flocs and sludge dewatering), Applied Thermal Engineering, 58, pp. 217-223.

\section{Analiza wielkości cząstek oraz wymiarów fraktalnych zawiesin zawartych w ściekach surowych, oczyszczonych i osadzie czynnym}

Streszczenie: Analiza wielkości cząstek zawiesin metodą dyfrakcji laserowej pozwala uzyskać informacje nie tylko na temat wymiarów cząstek, ale także ich właściwości, kształtu oraz budowy przestrzennej, określanej na podstawie wartości wymiaru fraktalnego. Wymiar fraktalny pozwala na ocenę wnętrza agregatów, ukazując jednocześnie stopień złożoności obiektu. W literaturze dużo uwagi poświęca się ocenie wymiaru fraktalnego kłaczków osadu czynnego pod kątem kontroli procesów jednostkowych, tj.: sedymentacja, odwadnianie, koagulacja czy flokulacja, jednak wciąż brakuje wyników badań na temat wielkości cząstek i struktury zawiesin występujących w ściekach surowych i oczyszczonych.

W artykule przedstawiono określone za pomocą granulometru laserowego optyczne wymiary fraktalne $D_{3}$ i rozkłady wielkości cząstek w ściekach surowych, oczyszczonych i osadzie czynnym pobranych z sześciu mechaniczno-biologicznych oczyszczalni ścieków zlokalizowanych na terenie Dolnego Śląska.

Uzyskane wyniki badań wskazują, iż oczyszczalnie ścieków pracujące zarówno w układzie zarówno reaktorów wsadowych jak i przepływowych powodują skuteczniejsze zatrzymywanie cząstek zawiesin o rozmiarach cząstek do $30 \mu \mathrm{m}$ oraz podwyższone wynoszenie do odpływu cząstek w zakresie rozmiarów od $30 \mu \mathrm{m}$ do $600 \mu \mathrm{m}$. Dodatkowo w przypadku próbek ścieków oczyszczonych i osadu czynnego pobieranych w tym samym miejscu i krótkich odstępach czasu zaobserwowano podobne rozkłady występowania cząstek. W przypadku analizy wymiarów fraktalnych najmniejszymi wartościami wymiaru fraktalnego (mediana równa 1,89 ) charakteryzowały się cząstki tworzące zawiesinę ścieków surowych, a najwyższymi cząstki osadu czynnego (mediana równa 2,2), co świadczy o tym, że budowa przestrzenna cząstek zawiesin zawartych w ściekach surowych była zbliżona do struktur liniowych z dużą ilością otwartych przestrzeni, a struktura cząstek tworzących zawiesinę osadu czynnego była znacznie bardziej rozbudowana przestrzennie. 